\title{
Physiological and biochemical effects of morphactin IT 3233 on callus and tumour tissues of Nicotiana tabacum L. cultured in vitro
}

I. Growth and nitrogen compounds content

\section{Z. CHIREK}

Department of Plant Physiology, Institute of Physiology and Cytology, University of Łódź, Poland

(Recelved: June 16, 1973.)

\section{Abstract}

A significant limitation of callus tissue growth was noted in Nicotiana tabacum L. cultured in vitro under the influence of morphactin IT 3233 applied in $10-40 \mathrm{mg} / \mathrm{dm}^{3}$ concentrations. Growth inhibition was associated with an increase in dry mass content and the contribution of protein $\mathrm{N}$ to the nitrogen pool. Tumour tissue of tobacco under the same conditions reacted weaker to morphactin. Growth limitation reached 25 per cent as compared with the control, dry mass and nitrogen compounds content showed only slight variations.

It is supposed that the different sensitivity of both types of tissues to morphactin is connected with their different hormonal metabolism.

\section{INTRODUCTION}

In the period $1960-1963$ in the E. Merck AG laboratories a number of fluorene derivatives showing biological activity were synthesized. These compounds have been described by Schneider (1964) as a new type of growth regulators and called morphactins. They act on plant morphogenesis by influencing cell division, phenomena of polarity and correlation and they abolish normal geo- and photo-tropic reactions of plants. Closer data concerning this subject may be found in several papers (P i e ni ą ż ek, S a n i e w s k i, 1967, 1969; $\mathrm{S}$ c hneid e r, 1970; Z i e g l e r, 1970).

According to $\mathrm{Ziegler}$ (1970) morphactins act via endogenous 
growth regulators, but not in direct interaction with them. Schneid e r (1970) believes that they may act multidirectionally through enzymatic systems.

The present study was undertaken to investigate the influence of morphactin IT 3233 on the growth of callus and tumour tissue of Nicotiana cultured in vitro. It is known that morphactins act in the first place on young tissues and in in vitro cultures these tissues acquire an embryonal character in a certain sense (B ute n ko, 1964).

On the other hand, callus and tumour tissues differ in the metabolism of growth substance. Tumour tissue produces them itself, while callus takes them up from the medium. Therefore comparison of the reaction of these tissues to morphactin seemed interesting.

In view of the relations between nitrogen metabolism and growth, the level of nitrogen compounds was studied in the tissues treated with morphactin.

\section{MATERIAL AND METHODS}

The investigations were carried out on callus and bacterial tumour tissues of Nicotina tabacum L. var. White Burley cultured on M u r a s$\mathrm{hige}$ and Skoog medium (1962) in the modification of Lins$\mathrm{m}$ a yer-Bednar and Skoog (1964). The medium for callus culture was supplemented with auxin (IAA) in the amount of $2 \mathrm{mg} / \mathrm{dm}^{3}$ and kinetin $0.25 \mathrm{mg} / \mathrm{dm}^{3}$. Tumour tissue grew without addition of these growth regulators.

To the standard media for both these types of tissue morphactin IT 3233 (n-butyl ester of 9-hydroxyfluorene-(9)-carboxylic acid, E. Merck AG) was added in doses of $1,5,10,20$ and $40 \mathrm{mg} / \mathrm{dm}^{3}$.

The tissues were cultured for 5 weeks in an incubator at $25^{\circ} \pm 1^{\circ} \mathrm{C}$ under constant light. After this time period, a part of the tissues from the standard medium (without morphactin) were passaged to fresh medium, and the remaining ones were used for analyses.

Tobacco tissues during the 5-6-week culture were in a state of active growth manifested by an increase in the cell numbers, in dry mass, nucleic acids phosphorus and protein content. Between the 6 th - 8th week the tissues attain their maximal mass, but at the cost of greater hydration. Then a relative decrease of dry mass occurs owing to the end of cell division ( $\mathrm{M}$ a roti 1966).

Growth measurem ents. About 150-mg fragments of callus and tumour tissue were inoculated on standard media and those supplemented with morphactin and cultured for 5 weeks. Then they were taken out of the test tubes, the medium was removed and each colony was wighed separately. A single series contained 13-14 colonies in the particular variants. The mean fresh mass of the tissue was 
calculated. The weighed tissues were then placed in a drier set at $100^{\circ} \mathrm{C}$ for one hour. Thereafter the temperature was lowered to $80^{\circ} \mathrm{C}$ and the tissues were dried to constant weight, weighed and the percent of dry mass was calculated.

The determinations were reapeated at least 6 times at various intervals.

Determination of nitrogen compounds. Nitrogen compounds were fractionated after $\mathrm{Th}$ i m a n $\mathrm{n}$ et al. $(1957,1960)$. This method consists in extraction of the particular fractions by means of trichloroacetic acid (TCA) at various temperatures. Protein remains in the sediment.

For the analyses 100-mg quotients of dried powdered tissues were used. Nitrogen content was determined by Kjeldahl's method in a Parnas-Wagner apparatus (according to Biełozierski and Proskuriakov, 1954). Titration was performed against the Tashiro reagent. The analyses were repeated six times.

\section{RESULTS}

Tissue appearance. Tobacco callus tissue forms rounded compact convex colonies cream-white in colour. The surface is uniformly white and fluffy. This tissue cultured on a medium with morphactin in 10,20 and $40 \mathrm{mg} / \mathrm{dm}^{3}$ concentrations changes in appearance. The colonies are flatter with outlined contours, the edges are usually fluffy and the centre of the colony transparent. With increasing morphactin concentration a progressive inhibition of tissue growth is observed (Photo 1).

Tumour tissue forms hard convex colonies with granular structure, yellowish in colour. Addition of morphactin to the medium does not produce any major changes in the appearance of the tumour tissue and causes a slight growth inhibition (Photo 1).

Analysis of growth (Table 1). Morphactin in a $1 \mathrm{mg} / \mathrm{dm}^{3}$ concentration stimulates somewhat the growth of callus tissues; in 5, 10,20 and $40 \mathrm{mg} / \mathrm{dm}^{3}$ concentrations it inhibits in $14-59$ per cent growth as compared with the control. A reverse tendency is observed in the dry mass content. At morphactin concentrations of $10-40 \mathrm{mg} / \mathrm{dm}^{3}$ the dry mass content rises to $11--28$ per cent as compared with that in control tissues (Table 1, Diagram 1).

In tumour tissues morphactin reduces growth by 14- -26 per cent as compared with the controls. The dry mass content increases slightly at lower morphactin concentrations (Table 1, Diagram 2).

When the growth of both kinds of tissue is compared, a somewhat slower rate of fresh mass increment is observed in the tumour tissues, but a higher dry mass content as compared with the callus. Callus 

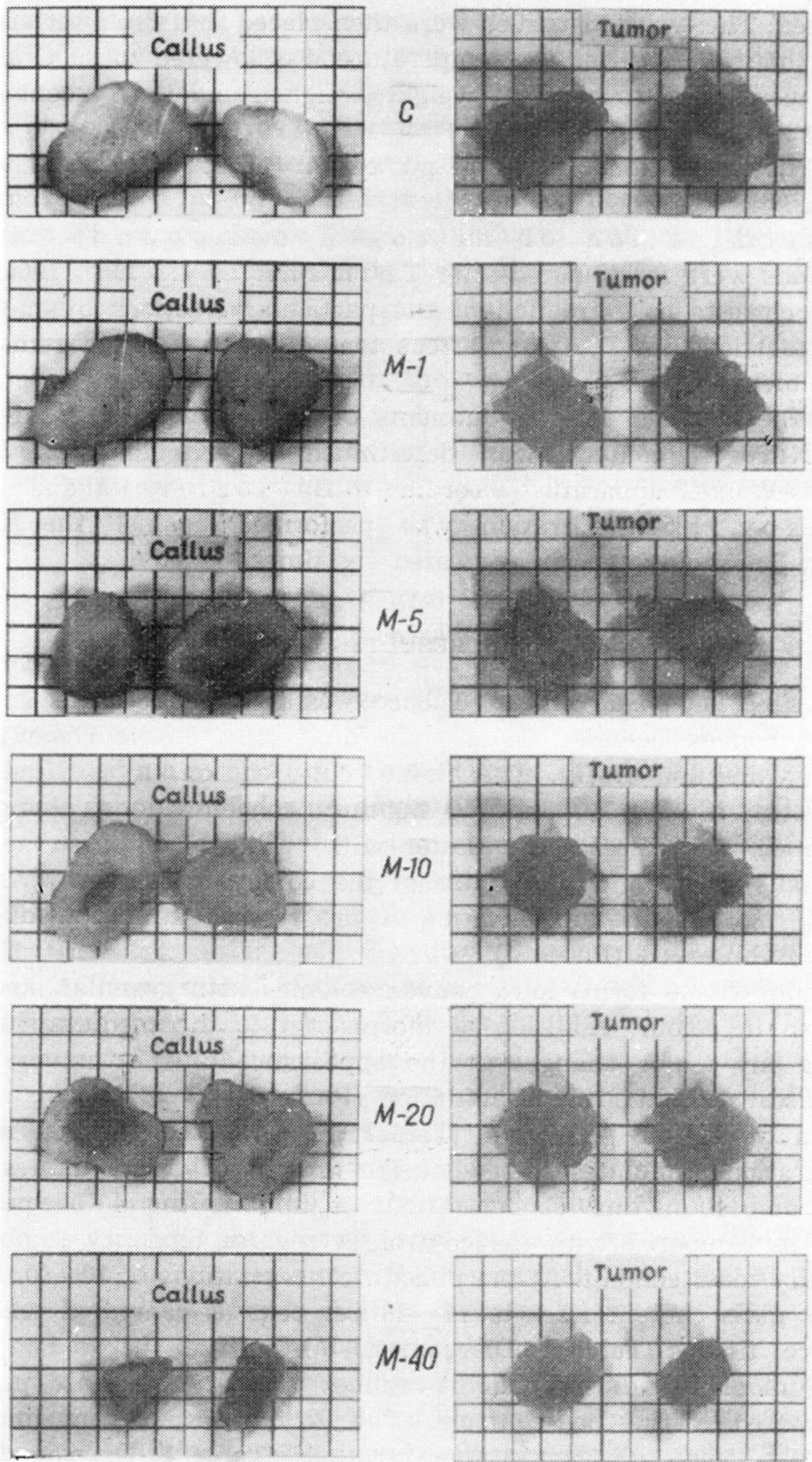

Photo. Callus and tumour tissue of Nicotiana tabacum L. after 5 weeks of growth in vitro

C - control (medium without morphactin). M-1... M-40 - medium with morphactin in $1 \ldots$ $40 \mathrm{mg} / \mathrm{dm}^{3}$ concentrations 


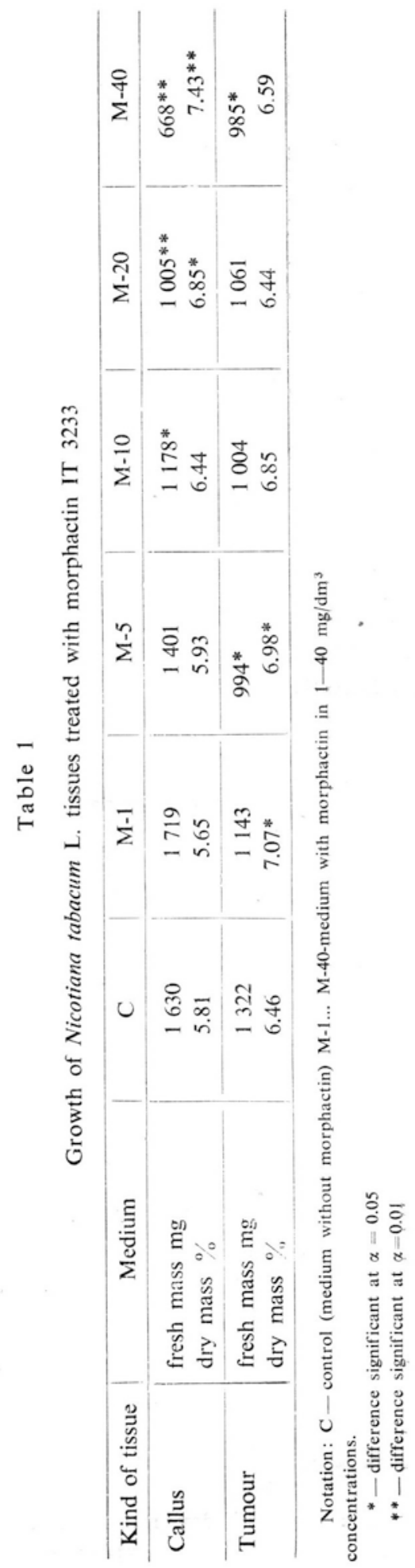




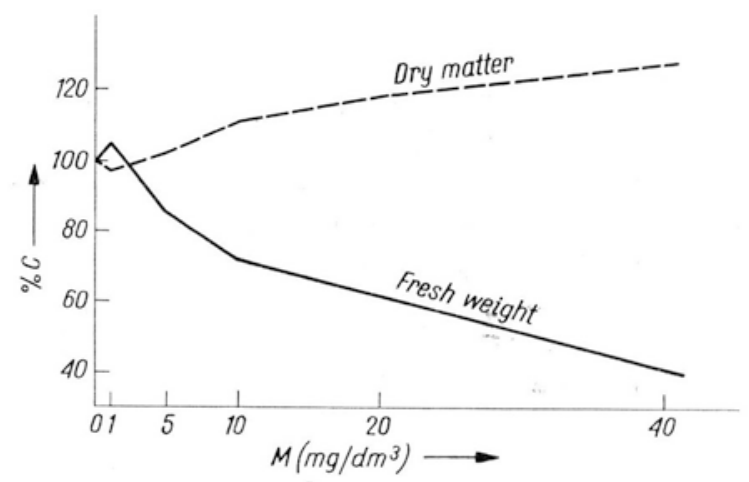

Diagram 1. Increase in and content of dry mass in callus tissues of tobacco cultured in vitro on medium with morphactin (M), expressed as per cent of control

tissues are more sensitive to morphactin than are tumour tissues. This may be seen in their appearance, marked growth inhibition and an increase in dry mass content.

Nitrogen compounds. The total content of nitrogen compounds (per dry mass unit) in callus tissues cultured on the medium with morphactin does not show major changes as compared with the controls (Table 2).

At higher morphactin concentrations a significant increase is noted in the contribution of protein nitrogen to total nitrogen at the cost of a small decrease in acid-soluble nitrogen. If these results are referred to a tissue dry mass, the nitrogen compounds content is maximally increased by 30 per cent (at $40 \mathrm{mg} / \mathrm{dm}^{3}$ morphactin dose).

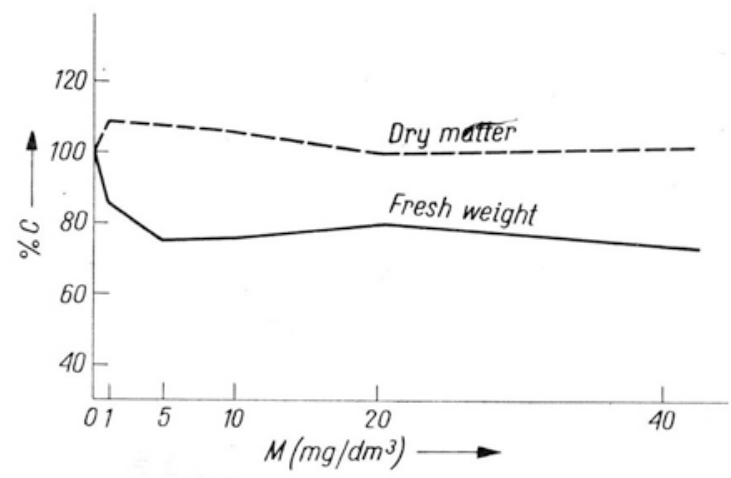

Diagram 2. Increase in and content of dry mass in tumour tissues of tobacco cultured on medium with morphactin (M), expressed as per cent of control 


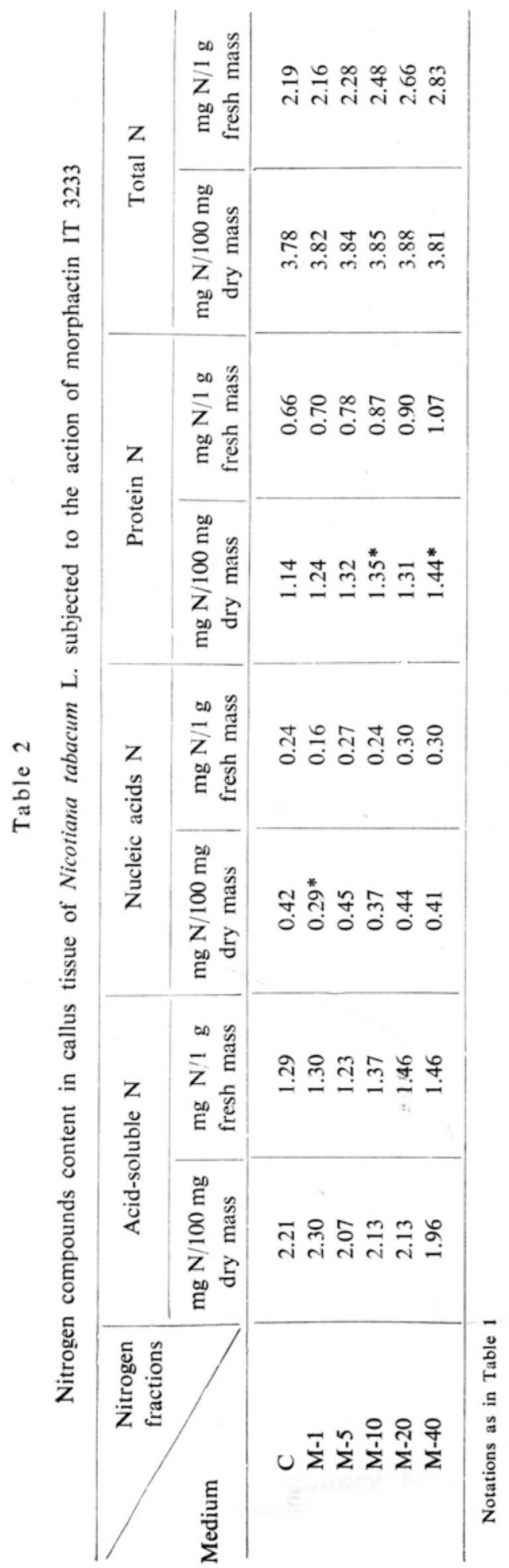




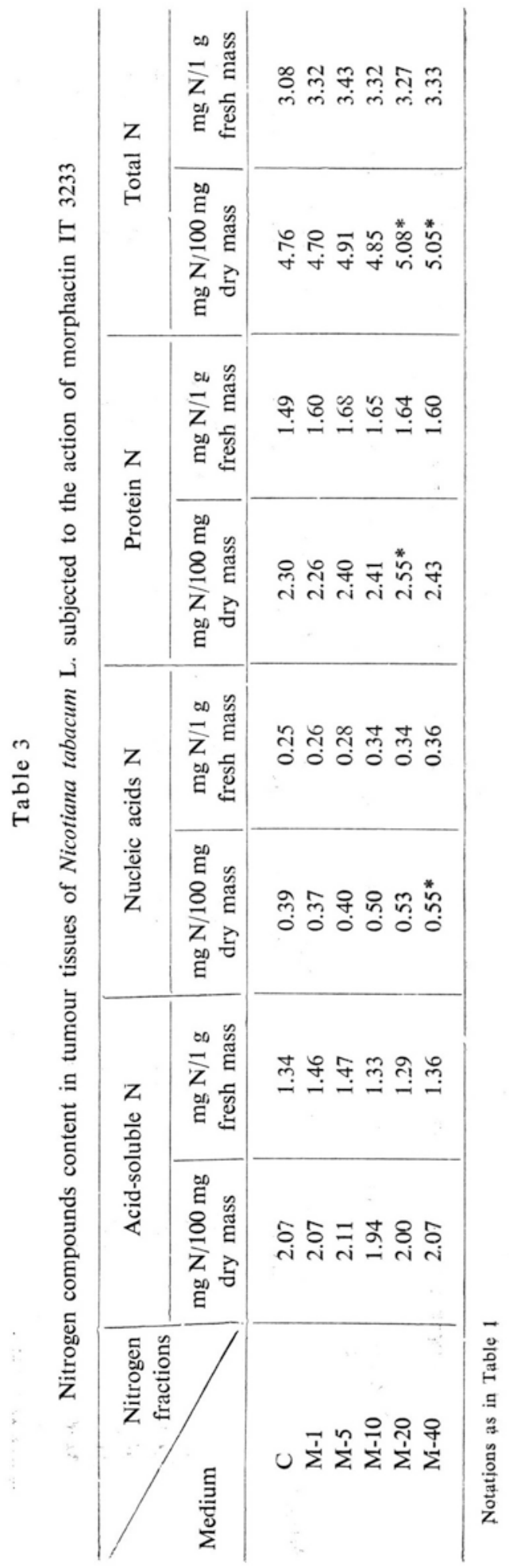


It is the protein fraction which shows the greatest increment, the acid-soluble and nucleic acid fractions increase less (Table 3).

In tumour tissue morphactin in 20 and $40 \mathrm{mg} / \mathrm{dm}^{3}$ concentrations causes a slight increase in nitrogen compounds (in reference to dry mass). Protein and nucleic acids $\mathrm{N}$ increases mainly. When calculated to a tissue fresh mass, the tendency is similar.

Comparison of control callus and tumour tissues indicates that nitrogen content is about 25 per cent higher in the tumour tissues (in relation to dry mass), protein nitrogen constituting about 50 per cent of total nitrogen, whereas in callus tissues it is only 30 per cent.

The higher nitrogen and protein level in tumour tissues as compared with that in normal ones has already been reported (Kle in, 1952; Lee 1952, Maciejewska-Potapczykowa and Niedzielski, 1962; Rennert, 1968).

\section{DISCUSSION}

On the basis of the results obtained it would seem that morphactin IT 3233 in $10-40 \mathrm{mg} / \mathrm{dm}^{3}$ concentrations has a significant influence on the growth and metabolism of callus tissue of tobacco.

The same substance used in the test with Galium also exhibited a distinct effect, beginning with a concentration of $10 \mathrm{mg} / \mathrm{dm}^{3}$, and a weak effect in the amount of $0.1 \mathrm{mg} / \mathrm{dm}^{3}$ (S c h neide r, 1964).

In tumour tissue of Nicotiana a weaker effect on growth was noted (at the same concentrations). Any correlation cannot be found between the concentration of this substances and the amount of reaction as it could be demonstrated in the case of callus tissue.

The action of morphactins on plant tissues in in vitro culture has not been more extensively studied. Recently Bednar and Linsm a yer-B e d n a r (1971) described the neoplastic transformation of the tissues of the tobacco variety Wisconsin 38 cultured with some morphactins and aminofluorenes. These tissues were capable of growing in the absence of cytokinin.

Earlier stimulation of the callus formation in plant explantates has been observed (in bean - Schneider 1967, in grape-vine J u $1 \mathrm{l}$ i a r d 1966, Alleweld and Bourquin 1967) after application of low morphactin concentrations.

These data indicate that morphactin in small doses stimulates the explantate cells to proliferation.

More frequently, however, an inhibitory action of morphactins on plant growth has been reported. This is probably due to the fact that they accumulate morphactins in the meristematic tissues ( $\mathrm{Schnei-}$ 
der 1970). Ringe and Denffer (1967) observed the mitosis inhibition by morphactin in concentrations as low as $0.1--1 \mathrm{mg} / \mathrm{dm}^{3}$.

Inhibition of callus and tumour tissue growth in tobacoo by morphactin is perhaps associated with the influence of regulators of this type on young tissues. The weaker reaction of tumour tissue may be due to its different metabolism, particularly as regards to growth substances.

Inhibition of growth of callus tissues occurred together with an increase in dry mass content. In tumour tissues this increase was smaller and was noted only at low morphactin concentrations. L orenzen and Weisbrich (1969) also observed a considerable increment of dry mass in Cardamine seedlings with growth delayed by morphactin.

The increase in dry mass content may be caused by more intensive synthesis or inhibition of degradation processes. It would seem that the dry mass increment in tissues treated with morphactin is associated with the inhibition of decomposition processes, for instance by the limitation of respiratory metabolism, but this requires further verification.

Determinations of nitrogen compounds indicate that their contribution to the dry mass of callus tissues does not change, thus their amount increases proportionally to the increase in the dry mass content as a whole. On the other hand, the contribution of protein nitrogen distinctly increases at the cost of the acid-soluble nitrogen fraction in callus tissues treated with morphactin.

The tumour tissues show a slight increase in total nitrogen due to a certain increment of protein nitrogen, when higher morphactin concentrations are applied.

These results prove that morphactin may act by disturbing the nitrogen metabolism. Buchenauer and Grossmann (1969) were the first to report changes in the free amino acids level in tomatoes treated with morphactin, and $\mathrm{Kr}$ is h che n k ot al. (1969) described a rise in the protein level in wheat subjected to the action of morphactin.

These preliminary data show that morphactin IT 3233 has a particular effect on the callus tissue metabolism, leading to significant growth inhibition. Tumour tissue is less sensitive to this agent. It remains to be elucidated by which pathway this influence runs. Changes in the protein fraction content indicate that this action may directly or indirectly involve protein synthesis. The differences in the reaction of callus and tumour tissue suggest that a different hormone metabolism in these tissues may be responsible for them. 
The author wishes to thank professor W aclawa $\mathrm{P}$ ot a p c z y k o w and $\mathrm{dr} A \mathrm{Adona} \mathrm{R}$ en $\mathrm{n}$ ert for their valuable advice and guidance in the course of this study and for a discussion of the results.

\section{REFERENCES}

A lleweldit B., B o urquin H. D., 1967. Wirkung von Chlorflurenolmethylester auf das Kallus- und Wurzelwachstum der Rebe. Naturwissenschaften 54: 542.

B ednar T. W., Lin s m a y r-B ednar E. M., 1971. Induction of cytokiminimdependent tobacco tissues by substituted fluorenes. Proc. Nat. Acad. Sci. USA 68(6): 1178-1179.

Buchenauer H., Grossmann F., 1969. Einflus von Morphaktinen auf verschiedene Tomatenkrankheiten, Ber. Deut. Bot. Ges., Vortr. Gasamtgeb. Bot., NF 3: $149-160$.

But enko R. G., 1964. Kultura izolirowannikh tkaniej i fiziologiya morfogeneza rastienii. Izd. „Nauka”, Moskva.

Jul1iard B., 1966. Action d'un dérivé du fluorénol sur la prolifération et la differenciation de boutures de vignes (Vitis vinifera L.). C. R. Acad. Sci. Paris, Ser. D. 262: 273-276.

K le in R. M., 1952. Nitrogen and phosphorus fractions, respiration and structure of normal and crown-gall tissues of tomato. Plant Physiol. 27: 335-354.

Krishchenko W. P., Dmitruk A. P., M a khd a d M., 1969. Wliyanie morfaktinov na obmien bielkov $v$ rastieniyakh pszenicy. Dokl. Akad. Nauk SSR 188: 233-234.

L e e A. E., 1952. Nitrogen and amino acids in normal, hablituated and bacteria free crown-gall tumor tissue culture of grape. Plant Physiol. 27: 173-178.

L insmayer-Bednar E. M., Skoog F., 1965. Organic growth factor requirements of tobacco tissue cultures. Physiol. Plant. 18: 100-127.

Lorenzen H., We is brich J., 1969. Zur Wirkung eines Morphaktins auf Rheo spathacea und Cardamine chenopodifolia. Ber. Deut. Bot. Ges., Vertr. Gesamtgeb. Bot., NF 3: 103-116.

Maciejewska-Potapczy kow a W., Niedzielski A., 1962, Zawartość związków azotu w tkankach zdrowych i tumorach niektórych roślin. Acta Soc. Bot. Pol. 31(1): 95-101.

M a roti M., 1966, Limits of growth in isolated tobacco tissues. Acta Biol. Acad. Sci. Hung. 16: 369-382 (wg BA).

M urashigle T., Skoog F., 1962, Revised medium for rapid growth and bioassays with tobacco tissue cultures. Physiol. Plant. 15: 473-497.

Pieniąż ek J., S a n i e w ski M., 1967, Morfaktyny - nowa grupa regulatorów wzrositu. Postępy Nauk Rolniczych 6(108): 39-52.

Pi eni ąż ek J., S a n i e w s ki M., 1969. Nowe dane o morfaktynach i możliwościach praktycznego zastosowania w rolnictwie i ogrodnictwie. Postępy Nauk Rolniczych 3/4 (117): 27-38.

Rennert A., 1968. Biochemiczna charakterystyka tkanek Nicotiana tabacum L. stymulorwanych pyłkiem pszczelim $\mathrm{w}$ hodowli in vitro. Zesz. Nauk. Uモ, s. II, 30: $69-80$.

R inge F., Denffer D., 1967. Zur Kenntnis der Wirksamkeit von 2-Chlor-9-fluorenol-9-carbonsäure bei Begonia semperflorens gracilis und Allium cepa. Wiss. Z. Univ. Rostock, Math.-Naturwiss. Reihe 16: 693-697. 
Schneider G., 1964. Eine neue Gruppe von synthetischen Pflanzenwachstumsregulatoren. Naturwissenschaften 51: 416-417.

S chneider G., 1967. Wirkung von Morphaktinen auf Kallus- und Adventivwurzelbildung an Hypokotylzylindern von Phaseolus vulgaris L. Wiss. Z. Univ. Rostock, Math.-Naturwiss. Reihe 16: 699-702.

S chneider G., 1970. Morphactins: Physiology and Performance. Ann. Rev. Plant Physiol. 21: 499-536.

Thimann K. V., Loos G. M., 1957. Protein synthesis during water uptake by tuber tissue. Plant Physiol. 32(4): 274-279.

Thimann K. V., Laloraya M. M., 1960. Changes in nitrogen in pea stem section under the action of kinetin. Physiol. Plant. 13: 165-178.

Z i e g l e r H., 1970. Morphactins. Endeavour 29(108): 112-116.

\author{
Author's address: \\ Dr Zofia Chirek-Kępczyńska \\ Department of Plant Physiology, \\ Institute of Physiology and Cytology, \\ University of Łódź, \\ ul. Nowopotudniowa $12 / 16$ \\ 90-273 Łódź. Poland
}

\begin{abstract}
Fizjologiczne $i$ biochemiczne efekty dzialania morfaktyny IT 3233 na tkanki-kalusowa $i$ tumorowa Nicotiana tabacum $L$.

$w$ hodowli in vitro
\end{abstract}

I. Wzrost i zawartość związków azotu

\title{
Streszczenie
}

Morfaktyna IT 3233 zastosowana do hodowli tkanek - kalusowej i tumorowej Nicotiana tabacum L. in vitro wywoływała hamowanie wzrostu tkanki kalusowej o 14-59\% przy stężeniach $5-40 \mathrm{mg} / \mathrm{dm}^{3}$, a thanki itumorowej o $14-26 \%$ przy stężeniach $1-40 \mathrm{mg} / \mathrm{dm}^{3}$ w porównaniu do kontroli. Hamowaniu wzrostu tkanek kalusowych towarzyszyły zmiany w wyglądzie (spłaszczenie) oraz podwyższenie poziomu suchej masy o 11-28\%. Ogólna zawartość związków azotu w odniesieniu do suchej masy tkanek nie zmieniła się pod wpływem morfaktyny w tkankach kalusowych, a w tumorowych ulegała niewielkiemu podwyższeniu. Natomiast wzrastał wyraźnie udział N-białkowego kosztem N-kwasorozpuszczalnego $\mathrm{w}$ tkankach kalusowych traktowanych morfaktyną.

Potwierdzono wyższą zawartość związków azotu, w tym białek, w tkance tumorowej w porównaniu do kalusowej.

Większa wrażliwość tkanki kalusowej na działanie morfaktyny może być związana z różną gospodarką hormonalną w tkance kalusowej i tumorowej. 